\title{
PERANCANGAN SISTEM INFORMASI PENJUALAN PADA PERUSAHAAN JASA SERVICE PROVIDER
}

\author{
Lianawati Christian; Mulfasli Urfan \\ Computerized Accounting Department, School of Information Systems, Binus University \\ Jln. K.H. Syahdan No. 9, Palmerah, Jakarta Barat 11480 \\ Liana_ch1309@binus.ac.id
}

\begin{abstract}
Along with the development of technology, every line of business as well as services needs information systems to support the company operations. This research is objected to analyze, identify information needs, repair and design accounting information system of service sales required by the management to support decision making and address the issues in the running system on a service company. Several methods were carried out on this research, such as data collection and information; analyses on the running system; analyses of research findings;, identification of information needs, and identification of system requirements, as well as object-oriented design methods, namely the problem domain analysis, application domain analysis, architecture design and component diagram. The results obtained in the form of improvements in the running system which was an application that informs the design of document numbering, filing, and reports. The accounting information system of service sales at the studied company produced needed reports timely, completely and accurately that can be utilized by the management in decision-making.
\end{abstract}

Keywords: analysis, desain, accounting information system, sales, services

\begin{abstract}
ABSTRAK
Seiring dengan perkembangan teknologi, setiap bidang usaha termasuk jasa membutuhkan sistem informasi yang dapat menunjang kegiatan operasional perusahaan. Tujuan penelitian adalah untuk menganalisis, mengidentifikasi kebutuhan informasi, memperbaiki dan merancang sistem informasi akuntansi penjualan jasa yang dibutuhkan oleh pihak manajemen untuk menunjang pengambilan keputusan serta mengatasi masalah dalam sistem yang berjalan pada sebuah perusahaan jasa. Penelitian dilakukan dengan metode pengumpulan data dan informasi; analisis meliputi penelitian atas sistem yang sedang berjalan, analisis terhadap temuan penelitian; identifikasi kebutuhan informasi, dan identifikasi persyaratan sistem; serta perancangan yang berorientasi objek, yaitu problem domain analysis, application domain analysis, architecture design dan component diagram. Hasil yang dicapai berupa perbaikan sistem yang berjalan dalam bentuk perancangan aplikasi yang menginformasikan penomoran dokumen, pengarsipan dokumen, dan laporan. Sistem informasi akuntansi penjualan jasa pada perusahaan jasa ini dapat menghasilkan laporan yang dibutuhkan perusahaan secara cepat, lengkap dan akurat dan dapat digunakan pihak manajemen dalam proses pengambilan keputusan.
\end{abstract}

Kata kunci: analisis, perancangan, sistem informasi akuntansi, penjualan, jasa 


\section{PENDAHULUAN}

Menjelang era globalisasi tingkat persaingan antar perusahaan menjadi semakin kompleks. Oleh karena itulah pihak manajemen perusahaan membutuhkan suatu sistem informasi yang dapat memberikan petunjuk aktual mengenai kegiatan-kegiatan yang dilakukan oleh perusahaan. Sistem informasi yang tepat akan menghasilkan informasi yang cepat, akurat dan terpercaya. Informasi yang demikian dibutuhkan dalam rangka pengambilan keputusan strategis perusahaan agar dapat semakin maju. Sistem informasi akan mengumpulkan, memproses, menyimpan, dan menganalisis informasi untuk tujuan tertentu bagi pihak manajemen. Salah satu sistem informasi yang dibutuhkan oleh sebuah perusahaan adalah sistem informasi akuntansi. Sistem ini akan mengumpulkan data keuangan dari aktivitas perusahaan, mengubah data tersebut menjadi sebuah informasi keuangan, dan menyediakan informasi tersebut kepada pihak di dalam perusahaan. Salah satu aktivitas utama perusahaan adalah kegiatan penjualan. Penjualan merupakan salah satu fungsi penting untuk kelancaran operasional perusahaan, di mana perusahaan akan mendapat pendapatan dari hasil penjualan kepada pelanggan. Sistem informasi akuntansi penjualan yang baik dapat menghasilkan informasi yang akurat dan berkualitas untuk mendukung proses pengambilan keputusan yang tepat bagi perusahaan.

Objek penelitian adalah sebuah perusahaan yang bergerak dalam bidang penjualan jasa. Dimana penjualan jasa yang dilakukan adalah jasa service provider. Dimana informasi mengenai kegiatan transaksi penjualan jasa masih bersifat manual. Sehingga banyak ditemukannya kekurangankekurangan di dalam alur informasinya, seperti kurangnya formulir standar yang di gunakan, kurangnya laporan perusahaan yang digunakan dan belum adanya integrasi antar bagian. Masalah lain yang di temukan adalah tidak adanya nomor urut tercetak pada setiap formulir, dan sering hilangnya formulir yang menyebabkan kesalahan dalam pencatatan laporan akhir bulannya. Ruang lingkup yang akan dibahas lebih lanjut meliputi: (1) sistem informasi akuntansi penjualan jasa yang berkaitan dengan prosedur penjualan jasa yang dimulai dari disepakatinya kontrak hingga serah terima ketika proyek telah selesai; (2) sistem informasi akuntansi penjualan jasa yang berkaitan dengan prosedur pencatatan piutang, dan penagihan piutang yang berdasarkan termin-nya

Adapun tujuan dari penelitian ini yaitu: (1) mengidentifikasi kelemahan-kelemahan yang ada pada sistem berjalan; (2) menganalisis sistem informasi penjualan jasa yang sedang berjalan; (3) merancang sistem informasi akuntansi penjualan jasa; (4) memberikan rekomendasi atas sistem pengendalian internal perusahaan yang baik. Setelah diaplikasikan, diharapkan penelitian ini membawa manfaat sbb: (1) perusahaan dapat mengetahui kelemahan-kelemahan sistem yang berjalan saat ini dan dapat mengatasi kelemahan-kelemahan tersebut dengan penerapan sistem informasi akuntansi penjualan jasa yang baru; (2) perusahaan dapat memperoleh dan mengolah informasi akuntansi penjualan jasa dengan lebih cepat dan akurat; (3) dengan pengendalian internal yang baik perusahaan dapat meningkatkan kinerja yang lebih baik dalam kegiatan operasional sehari-hari.

\section{METODE}

Metodologi yang digunakan dalam penelitian ini adalah studi pustaka dan perancangan sistem yang berorientasi objek, yaitu problem domain analysis, application domain analysis, architecture design dan component diagram. perancangan database, perancangan layar, perancangan formulir dan perancangan laporan. Objek penelitian ini adalah perusahaan jasa yang menangani jasa-jasa telekomunikasi meliputi Survey transmisi, Engineering,intallation. Prosedur pada sistem yang berjalan terdiri dari prosedur mencari pelanggan, prosedur penjualan jasa, prosedur penagihan dan pembayaran piutang. 


\section{Sistem Informasi}

O’brien, James A. (2005, p28) mendefinisikan sistem informasi sebagai an organized means of collecting, entering, and processing data, and of storing, managing, controlling, and reporting information so that an organization can achieve its objectives and goal yang diartikan sebagai 'cara yang terorganisir dalam mengumpulkan, memasukkan, dan mengolah data, serta menyimpan, mengelola, mengontrol, dan melaporkan informasi sehingga suatu organisasi dapat mencapai tujuan dan targetnya. Rama dan Jones (2006) mendefinisikan sistem informasi sebagai a man-made system that generally consists of an integrated set of computer-based and manual components established to collect, store, and manage data, and to provide output information to users, yang diterjemahkan sebagai 'sebuah sistem buatan manusia yang umumnya terdiri dari serangkaian komponen berbasis komputer dan manual terintegrasi untuk mengumpulkan, menyimpan, dan mengelola data, serta memberikan informasi output ke pengguna Sistem informasi, dari dua definisi di atas dapat ditarik garis besar sebagai integrasi suatu cara terorganisir yang dapat mengumpulkan, memasukkan, dan memroses data, mengendalikan, dan menghasilkan informasi dengan berbasis proses manual atau komputer untuk mencapai sasaran dan tujuan organisasi.

\section{Sistem Informasi Akuntansi}

Menurut Bodnar dan Hopwood (2001, p1), "Sistem informasi akuntansi adalah kumpulan sumber daya, seperti manusia dan peralatan yang diatur untuk mengolah data menjadi informasi”. Sedangkan menurut Rama dan Jones (2006, p.4), "The Accounting information system is a subsystem of an MIS that provides accounting and financial information, as well as other information obtained in the routine processing of accounting transaction"yang diterjemahkan sebagai 'subsistem dari MIS yang menyediakan informasi akuntansi dan keuangan, dan informasi lainnya yang diperoleh dalam proses rutin transaksi akuntansi.

Selanjutnya Rama dan Jones (2006, p.4) mengemukakan bahwa jenis-jenis transaksi dalam sistem informasi akuntansi dibagi menjadi tiga, yaitu: (1) an acquisition (purchasing) cycle: the process of purchasing and paying for goods or services, yang artinya 'siklus akuisisi adalah proses pembelian barang dan service dan pengeluaran kas; (2) a conversion cycle: the process of transforming aquired into goods and service, yang artinya 'siklus konversi adalah suatu proses dalam mengubah barang setengah jadi menjadi barang jadi'; (3) a revenue cycle: the process of providing goods or services to customers and collecting cash, yang artinya 'siklus penerimaan adalah suatu proses yang memberikan barang atau jasa dari penjualan ke konsumen dan penerimaan kas.' Sistem Informasi Akuntansi menurut Romney dan Steinbart (2006,p.6) adalah a system that collects, records, stores, and process data to produce information for decision makers, yang diterjemahkan sebagai 'sebuah sistem yang mengumpulkan, catatan, toko, dan memproses data untuk menghasilkan informasi bagi para pengambil keputusan'. Adapun tujuan sistem informasi akuntansi penjualan menurut Wilkinson et al. (2000,p.416) yaitu: (1) mencatat pesanan penjualan dengan tepat; (2) mengindetifikasi pelanggan yang layak mendapatkan kredit; (3) mengirimkan produk atau melakukan pelayanan pada waktu yang tepat; (4) menagih piutang kepada pelanggan pada waktunya dengan jumlah yang tepat; (5) mencatat dan mengklasifikasikan penerimaan kas dengan tepat; (6) melakukan posting penjualan dan penerimaan kas ke akun-akun yang berhubungan ke dalam buku besar piutang; (7) mengamankan produk sampai pengiriman; (8) mengamankan kas sampai deposit.

\section{Analisis dan Desain Berorientasi Object}

Menurut Mathiassen et al. (2000,p.4), object adalah “ an entity with identity, state, and behavior. Setiap object tidak digambarkan secara sendiri - sendiri. Menurut Mathiassen et al. (2000,p4), class adalah "a description of a collection of object sharing stucture, behavioral pattern, and attributes. 
Keuntungan dari object oriented analysis and design (OOA\&D) adalah menyediakan infomasi yang jelas mengenai konteks sistem. Ada kaitan yang erat antara object-oriented analysis, objectoriented design, object-oriented user interface dan object-oriented programming. Obyek dapat menerangkan kondisi perusahaan beserta kondisi sosial ekonominya, sebaik system's interfaces, functions, processes, and components. Dalam analisis, pengembang menggunakan obyek untuk menentukan persyaratan sistem. Dalam desain, mereka menggunakan obyek untuk menggambarkan sistem tersebut. Pengembang juga menggunakan obyek sebagai konsep inti dalam programming. Notasi standar yang digunakan dalam OOA\&D adalah UML (Unified Modeling Languange). UML digunakan hanya sebagai notasi dan bukan sebagai metode dalam melakukan modeling. Metode ini memiliki beberapa tujuan, yaitu untuk: (1) menetapkan syarat sistem; (2) menghasilkan sebuah desain sistem tanpa ketidakpastian yang berarti; (3) memahami sebuah sistem, konteksnya, dan kondisi untuk implementasinya.

Ada beberapa metode yang digunakan dalam analisis dan desain sistem yang berorientasi object, di antaranya adalah: (1) rich picture, yaitu suatu gambar yang informal yang melukiskan pemahaman penggambar akan suatu situasi. Rich Picture secara umum menggambarkan permasalahan sistem dan application domain. Rich Picture tidak memiliki notasi khusus. Namun seharusnya melalui beberapa persetujuan di antara proyek sebagaimana aspek tertentu digambarkan; (2) UML class diagram, yaitu gambaran mengenai sekumpulan class dan hubungan antara class yang terstruktur. UML class diagram adalah pusat penggambaran dari analisis dan desain berorientasi object. Selama masa analisis, biasanya cukup untuk menggambarkan class dengan namanya, juga menggambarkan hubungan antara actor dan use case; (3) navigation diagram, yaitu jenis khusus dari statechart diagram yang berfokus pada dinamika keseluruhan dari tampilan layar. Diagram ini menunjukkan window-window yang bersangkutan dan perpindahan di antara mereka. Sebuah window ditunjukkan sebagai sebuah state. State memiliki sebuah nama dan sebuah icon. Pergantian state sesuai dengan pergantian di antara dua window.

\section{HASIL DAN PEMBAHASAN}

\section{Prosedur Mencari Pelanggan}

Prosedur mencari pelanggan merupakan suatu kegiatan yang diawali dengan sejak mendapatkan informasi adanya tender dari calon customer, pengajuan proposal kepada calon customer, diterimanya tender, registrasi perusahaan untuk menjadi vendor, hingga pengesahan kontrak.

\section{Bagian Marketing}

Aktivitasnya dimulai dengan adanya pengumuman di koran, internet, atau media lainnya, bisa juga melalui pemberitahuan dari kenalan. Setelah menerima kabar tersebut maka bagian marketing di perusahaan TENC akan membuat proposal mengumpulkan bahan-bahan, data-data, dan dokumendokumen yang dibutuhkan yang telah disiapkan bagian project dan diserahkan kepada perusahaan yang membuka tender.

\section{Bagian Project}

Bila pihak perusahaan calon customer menyetujui pengajuan tersebut maka direktur operasional akan melakukan negosiasi kepada calon customer. Dan bila dari negosiasi tersebut menghasilkan kesepakatan dengan pihak calon customer, calon customer akan mengeluarkan pengumuman penerimaan proyek. Pihak calon customer akan memberikan beberapa formulir untuk 
meregistrasi sebagai vendor untuk perusahaan calon customer, dan memberikan dokumen kontrak kepada bagian project untuk ditandatangani oleh pihak vendor yang berwewenang.

\section{Direktur Operasional}

Aktivitas yang dilakukan antara lain melakukan negosisasi harga dengan calon customer setelah tendernya diterima. Dan menandatangani kontrak proyek yang dibuat calon customer.

\section{Prosedur Penjualan Jasa}

Prosedur penjualan jasa merupakan suatu kegiatan yang diawali sejak diterimanya order/pesanan dari customer, pembuatan faktur/penagihan, penyelesaian pekerjaan yang dibuktikan dengan Acceptance Certificate, dan pencatatan penjualan.

\section{Bagian Proyek}

Aktivitasnya sebagai berikut: (1) mencatat semua order yang diterima dari seluruh customer; (2) menerima Purchase Order (PO) dari customer, dan mencatat jumlah dan jenis pekerjaan yang ada dalam PO. Apabila disetujui, segera ditandatangani oleh pihak yang berwenang (dalam hal ini direktur operasional) dan dikonfirmasikan ke customer sebagai pemberitahuan, sedangkan tembusannya diproses lebih lanjut ke fungsi-fungsi lainnya; (3) mengkonfirmasikan kepada perusahaan client/customer; (4) membuat Surat Perintah Kerja atas Purchase Order sebagai dasar kepada para pekerja (applicant) untuk memulai suatu pekerjaan; (5) membuat Request Suspense untuk estimasi biaya yang dibutuhkan untuk pengerjaan proyek, yang kemudian diberikan ke bagian Keuangan dan Akuntansi untuk mengeluarkan dana berdasarkan Request Suspense tersebut. Dan membuat Settlement Report setelah semua pengerjaan proyek selesai berupa laporan pertanggungjawaban biaya yang telah digunakan dan dibandingkan dengan Request Suspense; (5) penyesuaian estimasi (request suspense) dengan realisasi (Settlement report) dan diserahkan kepada bagian keuangan dan akuntansi; (6) memastikan bahwa pekerjaan yang dilaksanakan sesuai dengan spesifikasi dan permintaan dari customer, apabila disetujui oleh customer dibuktikan dengan ditandatanganinya acceptance certificate atau Berita Acara Serah Terima (BAST).

\section{Direktur Operasional}

Aktivitasnya sebagai berikut: (1) menyetujui Purchase Order yang diterima bagian Project; (2) menyetujui Surat Perintah Kerja yang dibuat bagian Project; (3) menyetujui Request Suspense yang dibuat di bagian Project untuk memberikan otorisasi kepada bagian keuangan dan akuntansi untuk memberikan dana kepada karyawan yang mengerjakan proyek; (4) menyetujui settlement report yang dibuat bagian project, bahwa laporan sesuai dengan request suspense.

\section{Applicant}

Aktivitasnya sebagai berikut: (1) menerima Surat Perintah Kerja (SPK) dari bagian Project; (2) membuat Request Suspence yaitu rincian biaya untuk kebutuhan selama pengerjaan proyek; (3) melakukan pekerjaan sesuai SPK hingga selesai.

\section{Bagian Pencatatan Transaksi dan Buku Besar (General Ledger)}

Bagian ini mencatat penjualan dari Purchase Order yang diterima dari bagian project sebagai suatu pendapatan. 


\section{Prosedur Penagihan dan Pembayaran}

Prosedur penagihan merupakan suatu kegiatan yang diawali sejak diterimanya order/pesanan yang disetujui Direktur operasional dari bagian proyek, pembuatan faktur/penagihan. penyelesaian pekerjaan yang dibuktikan dengan Acceptance Certificate, dan pencatatan piutang.

\section{Bagian Project}

Aktivitasnya adalah mengirim invoice (faktur penjualan) beserta dokumen-dokumen pendukungnya, yang telah disetujui oleh Direktur Operasional, kepada customer.

\section{Bagian Penagihan}

Aktivitasnya sebagai berikut: (1) setelah menerima purchase order dari bagian project yang telah disetujui oleh Direktur Operasional, proses selanjutnya adalah membuat/menerbitkan faktur penjualan satu rangkap untuk penagihan Down Payment atau penagihan periode pertama berikut dokumen pendukungnya; (2) membuat faktur penjualan periode kedua terakhir setelah pekerjaan proyek mencapai presentase tahap yang disepakati, dan untuk periode terakhir setelah pekerjaan proyek telah selesai atau tahap final. Faktur penjualan dibuat berikut tembusannya oleh bagian billing yang dilampirkan dengan dokumen-dokumen pendukung lainnya seperti acceptance certificate/BAST (Berita Acara Serah Terima), transmital form, dan purchase order; (3) memeriksa kebenaran penulisan dan perhitungan-perhitungan nominal yang disesuaikan dengan nominal yang tercantum di PO dan metode pembayaran sesuai dengan kontrak pekerjaan; (4) apabila seluruh dokumen penagihan telah lengkap, invoice diserahkan ke bagian proyek. Selanjutnya bagian proyek meminta approval kepada Direktur Operasional dan setelah disetujui, bagian proyek mengirimkan invoice tersebut kepada customer; (5) bagian ini juga mempersiapkan jurnal entry untuk setiap transaksi dan membuat daftar umur piutang (aging schedule).

\section{Direktur Operasional}

Aktivitasnya sebagai berikut: (1) menyetujui faktur penjualan Down Payment beserta dokumen-dokumen pendukungnya; (2) menyetujui faktur penjualan periode kedua dan berikutnya beserta dokumen-dokumen pendukungnya.

\section{Bagian Pencatatan Transaksi dan Buku Besar}

Tembusan invoice yang diterima dari bagian penagihan diproses di bagian General Ledger untuk dibuatkan jurnal transaksi piutang usaha maupun penjualan secara harian dan mem-post-nya ke dalam General Ledger (Account Receivable Ledger dan Sales Ledger) secara periodik.

Bagian ini mencatat piutang dan mengakui pendapatan setelah invoice untuk DP terbit dari bagian penagihan. Dan kembali mencatat piutang untuk penagihan sisa piutang saat proyek selesai dikerjakan atau berdasarkan termin-nya. Dan mencatat penerimaan atau pembayaran tagihan dari customer.

Gambar 1 berikut merupakan rich picture prosedur mencari pelanggan. Sedangkan Gambar 2 memuat prosedur penjualan jasa.

\section{Analisis Temuan Survey}

Hasil evaluasi yang dilakukan terhadap sistem adalah sebagai berikut: (1) perusahaan belum melakukan pencadangan atas kemungkinan tidak tertagihnya piutang usaha. Padahal untuk mengantisipasi piutang yang tertagih, perusahaan-perusahaan biasanya membuat kebijakan dengan membentuk rekening cadangan kerugian piutang; (2) pada sistem yang masih berjalan data kontrak dan invoice dapat dimanipulasi serta adanya data yang dimasukkan berulang seperti memasukkan 
tanggal,nomor order dan nomor invoice yang harus urut yang berbeda-beda berdasarkan nama customernya; (3) laporan yang dihasilkan sangat lambat sehingga tidak mampu memenuhi kebutuhan pihak manajemen akan informasi yang akurat dan terkadang ada beberapa data yang terlewat untuk dicatat; (4) tidak ada sistem yang dapat menampilkan daftar piutang pelanggan yang telah jatuh tempo secara otomatis.

\section{Overview Sistem Bisnis Usulan}

Pengembangan sistem informasi akuntansi penjualan jasa pada perusahaan ini dilakukan untuk mendukung pencatatan dan pengendalian internal atas transaksi harian penjualan dan piutangnya. Mulai dari kegiatan registrasi pelanggan baru, penerimaan pesanan pelanggan, penagihan, pencatatan pembayaran, dan penilaian pelanggan. Sistem informasi akuntansi penjualan yang digunakan perusahan sebagai alat bantu untuk menangani pencatatan aktivitas harian perusahaan yang berhubungan dengan penjualan menggunakan arsitektur client server. Setiap client dan server menggunakan PC biasa berbasis windows dan client akan terhubung pada server dengan menggunakan LAN. Pengembangan dilakukan berdasarkan usulan perbaikan dari permasalahan yang ditemui dalam aktivitas berjalan perusahaan. Untuk lebih jelasnya, system definition dari usulan sistem informasi akuntansi penjualan jasa dapat dilihat pada Tabel 1. Gambar 3 adalah UML class diagram sistem informasi penjualan jasa yang diusulkan.

\section{Rancangan Layar dan Laporan}

Gambar 4 dan 5 di bawah ini menampilkan layar menu login dan menu master karyawan. Selanjutnya Gambar 6 dan 7 menampilkan layar menu master customer dan master kontrak. Disusul Gambar 8 dan 9 yang menampilkan layar invoice dan layar list of account receivable. Berikutnya Gambar 10 - 14 menampilkan beberapa layar laporan.

\section{PENUTUP}

Berdasarkan hasil analisis dan perancangan sistem informasi akuntansi penjualan dan piutang usaha yang telah dilakukan pada perusahaan, diperoleh simpulan sebagai berikut: (1) perusahaan belum melakukan pencadangan atas kemungkinan tidak tertagihnya piutang usaha. Sistem usulan yang dirancang memberikan informasi saat invoice dientry data tersebut masuk ke dalam daftar piutang yang berisi nomor invoice, nomor order, tanggal invoice, tanggal jatuh tempo dan nilia kontraknya, dapat diketahui customer mana yang belum lunas dan akan ditagih serta yang sudah jatuh tempo dari reminder; (2) pada sistem yang masih berjalan, data kontrak dan invoice bisa sangat mudah mengalami kesalahan entry. Dengan sistem ini, nomor urut data kontrak dan invoice sudah tersedia sehingga user hanya memilih kode customer-nya dan kode pekerjaannya saja pada saat entry pesanan dan membuat invoice; (3) selama ini tidak ada sistem yang dapat menampilkan daftar piutang pelanggan. Sistem yang dibuat dapat mempermudah bagian keuangan dalam mengecek piutang pelanggan yang jatuh tempo lebih cepat.

Untuk perbaikan ke depannya, penulis mengemukaan beberapa saran sebagai berikut: (1) perlu dilakukan evaluasi secara periodik terhadap sistem informasi akuntansi penjualan yang sudah diterapkan, mencari kekurangan dan kelemahan sistem, dan mengembangkan sistem sesuai kebutuhan agar lebih efektif dan efisien; (2) perusahaan perlu mengembangkan teknologi informasi ke segala bidang tidak hanya pada bagian penjualan saja tetapi dapat dibuatkan sistem informasi untuk SDM, penggajian, dan sebagainya. 


\section{DAFTAR PUSTAKA}

Mathiassen, Lars. (2000). Object Oriented Analysis \& Design (first edition). Denmark:Marco Publishing.

O’Brien, James A. \& Marakas, George M. (2006). Management Information System ( th $^{\text {th }}$ edition). New York: McGraw-Hill.

Rama, Dasaratha V. \& Jones, Federick L. (2006). Accounting Information System: Canada: SouthWestern College Publishing.

Romney, Marshall B.\&Steinbart, Paul John. (2006). Accounting Information System (11 ${ }^{\text {th }}$ edition). New Jersey: Pearson Prentice Hall.

Wilkinson, Joseph W., Cerullo, Michael J., Raval, Vasant, Wong-On-Wing, Bernard (2000). Accounting Information System: Essential Concepts and application ( $4^{\text {th }}$ edition). New Jersey: John Wiley \& Sons.

\section{APPENDIX}

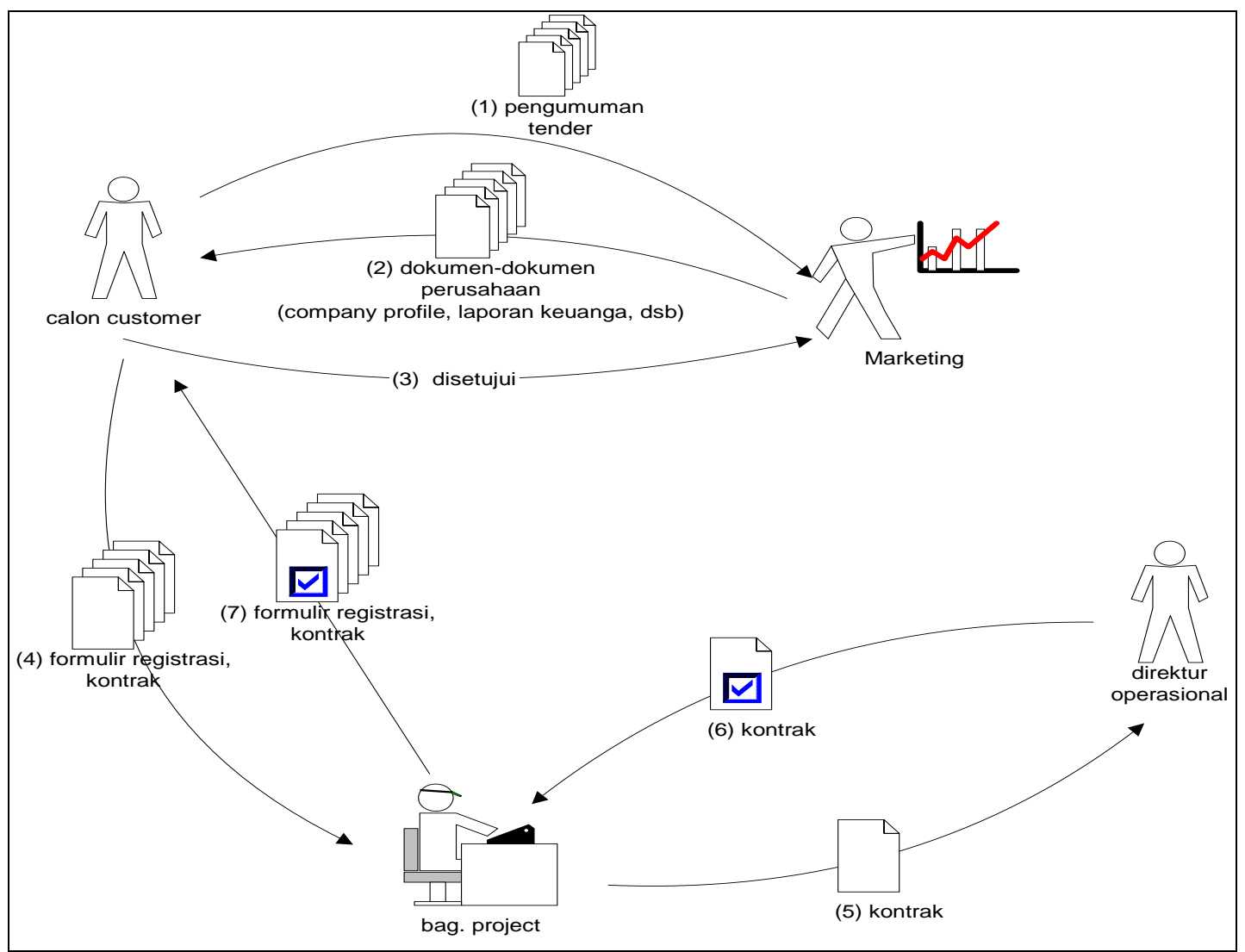

Gambar 1. Rich picture prosedur mencari pelanggan. 


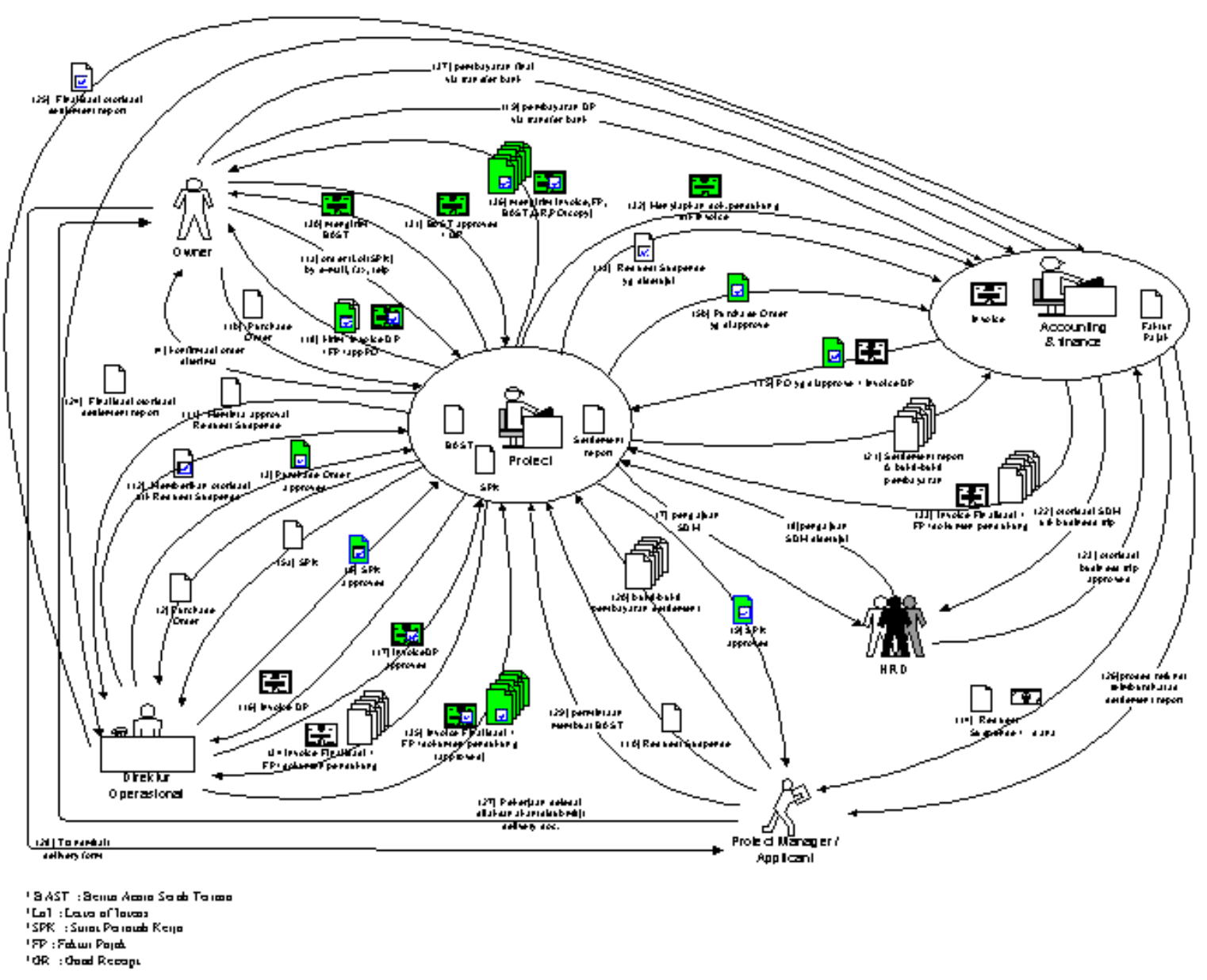

Gambar 2. Rich picture prosedur penjualan jasa.

Tabel 1

System Definition dengan Kriteria FACTOR

Functionality Mendukung pencatatan dan pengendalian kegiatan penjualan jasa sehingga dapat menghasilkan informasi penjualan jasa yang reliable dan up to date

\begin{tabular}{ll}
\hline $\begin{array}{l}\text { Application } \\
\text { Domain }\end{array}$ & Karyawan project, karyawan keuangan \& akuntansi \\
\hline Condition & $\begin{array}{l}\text { Sistem informasi akuntansi penjualan jasa ini dikembangkan berdasarkan usulan untuk mengatasi } \\
\text { permasalahan yang ditemukan dalam aktivitas penjualan jasa perusahaan }\end{array}$ \\
\hline Technology & $\begin{array}{l}\text { Menggunakan beberapa Personal Computer (PC) yang telah dilengkapi beberapa device umum lainnya } \\
\text { seperti printer, fax, dll. PC akan terhubung pada server dengan menggunakan jaringan komputer lokal } \\
\text { (LAN) }\end{array}$ \\
\hline Objects & Karyawan, kontrak, faktur penjualan/invoice, pembayaran, dan piutang \\
\hline Responsibility & $\begin{array}{l}\text { Alat administrasi yang cepat dan dapat diandalkan dalam pencatatan dan penyediaan informasi - informasi } \\
\text { transaksi harian penjualan jasa. }\end{array}$ \\
\hline
\end{tabular}




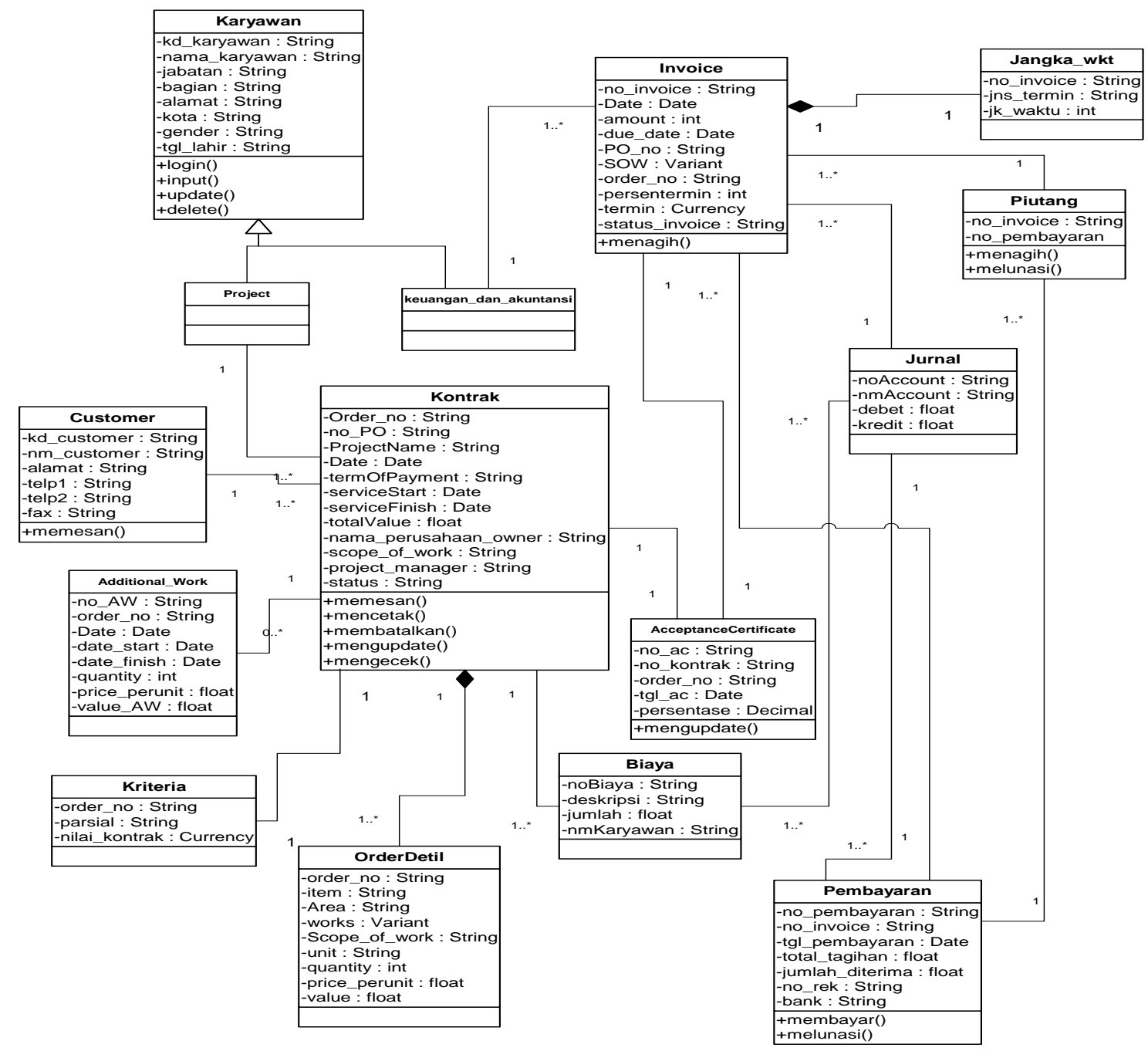

Gambar 3. UML class diagram usulan sistem informasi penjualan jasa.

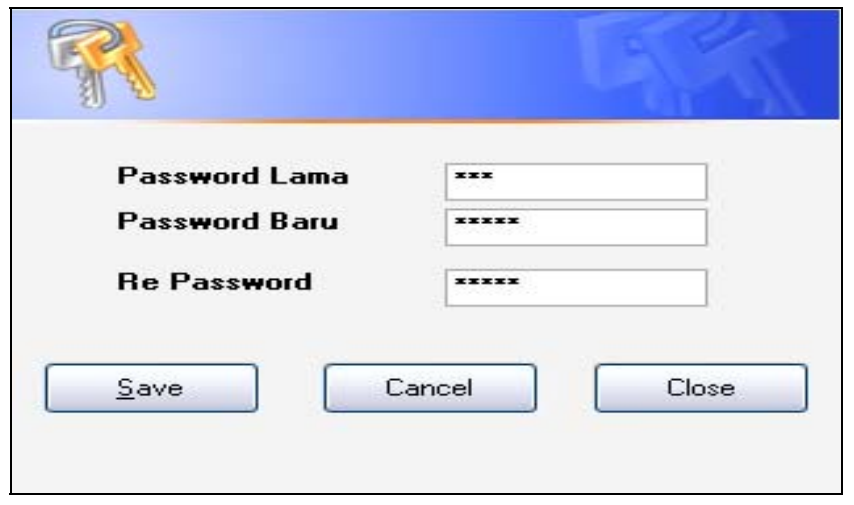

Gambar 4. Layar menu login.

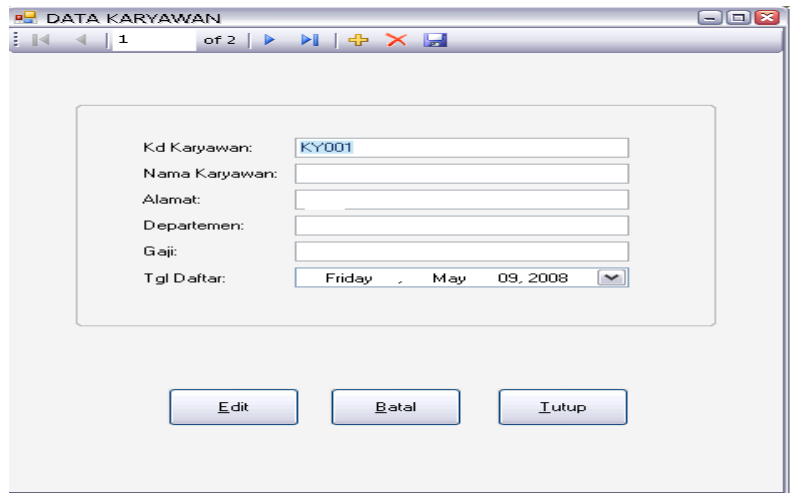

Gambar 5. Layar menu master karyawan. 


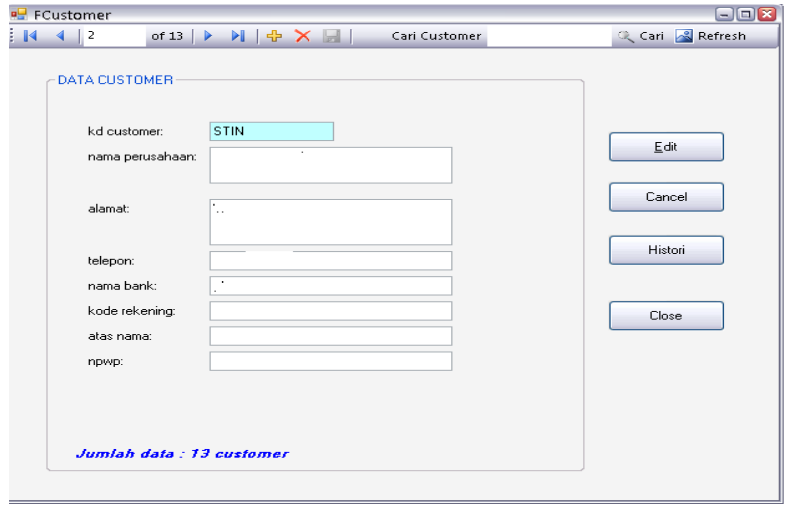

Gambar 6. Layar master customer.

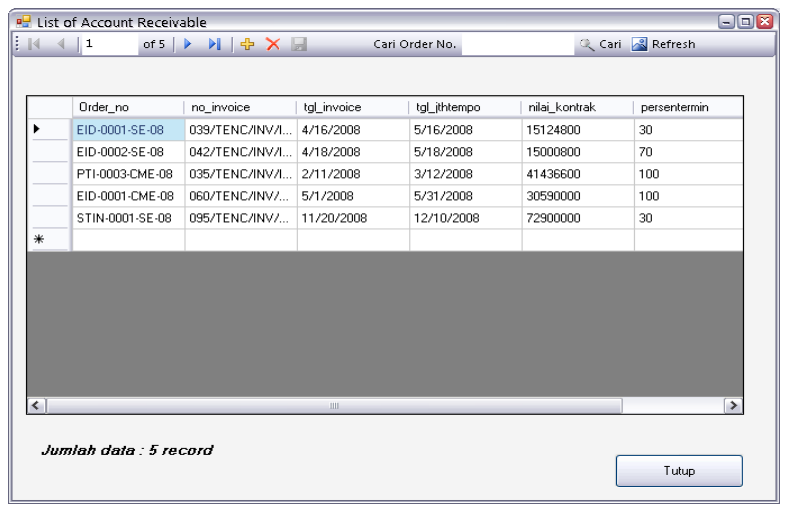

Gambar 8. Layar invoice.

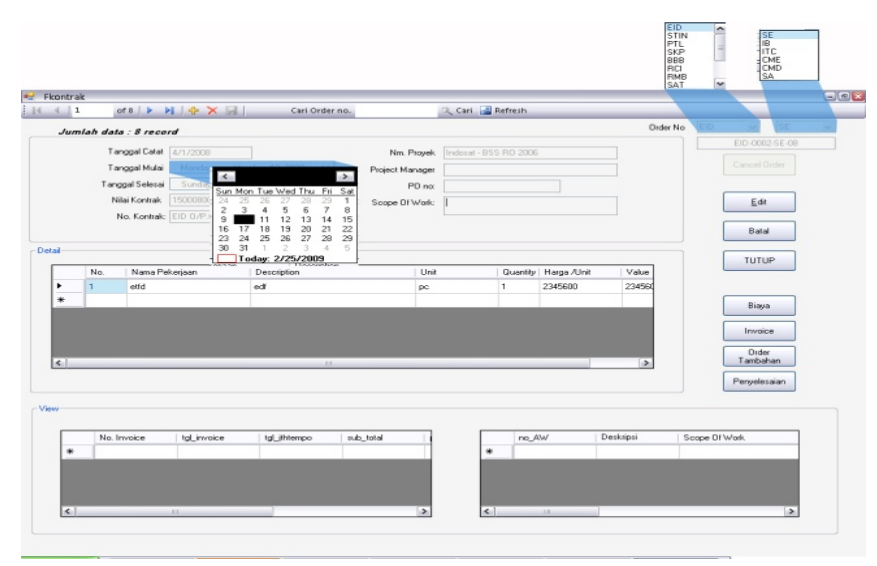

Gambar 7. Layar menu master kontrak.

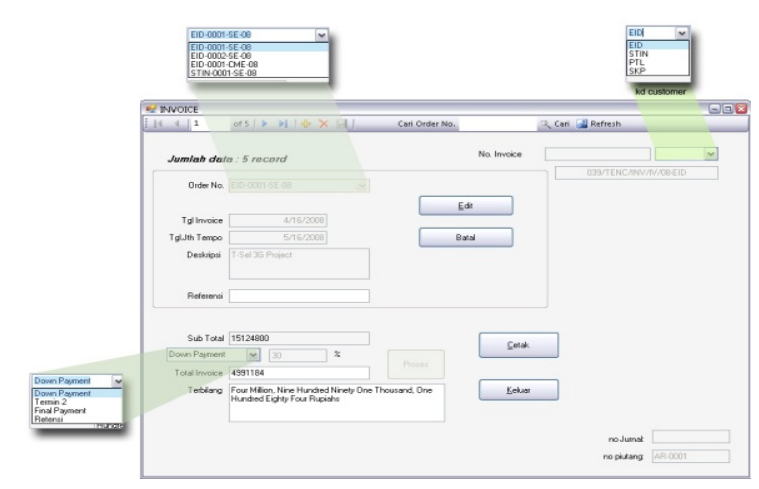

Gambar 9. Layar Menu list of account receivable. 


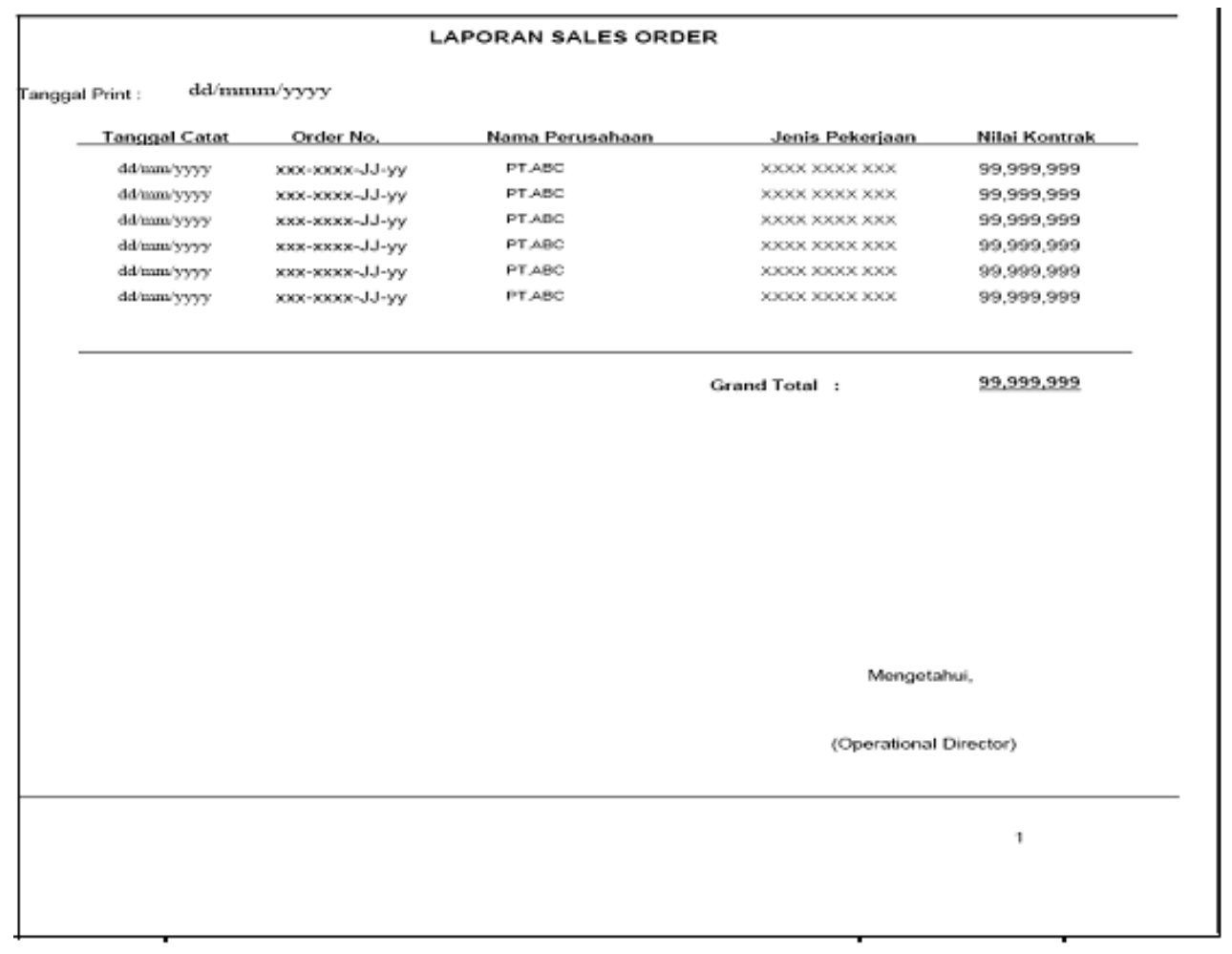

Gambar 10. Laporan sales order.

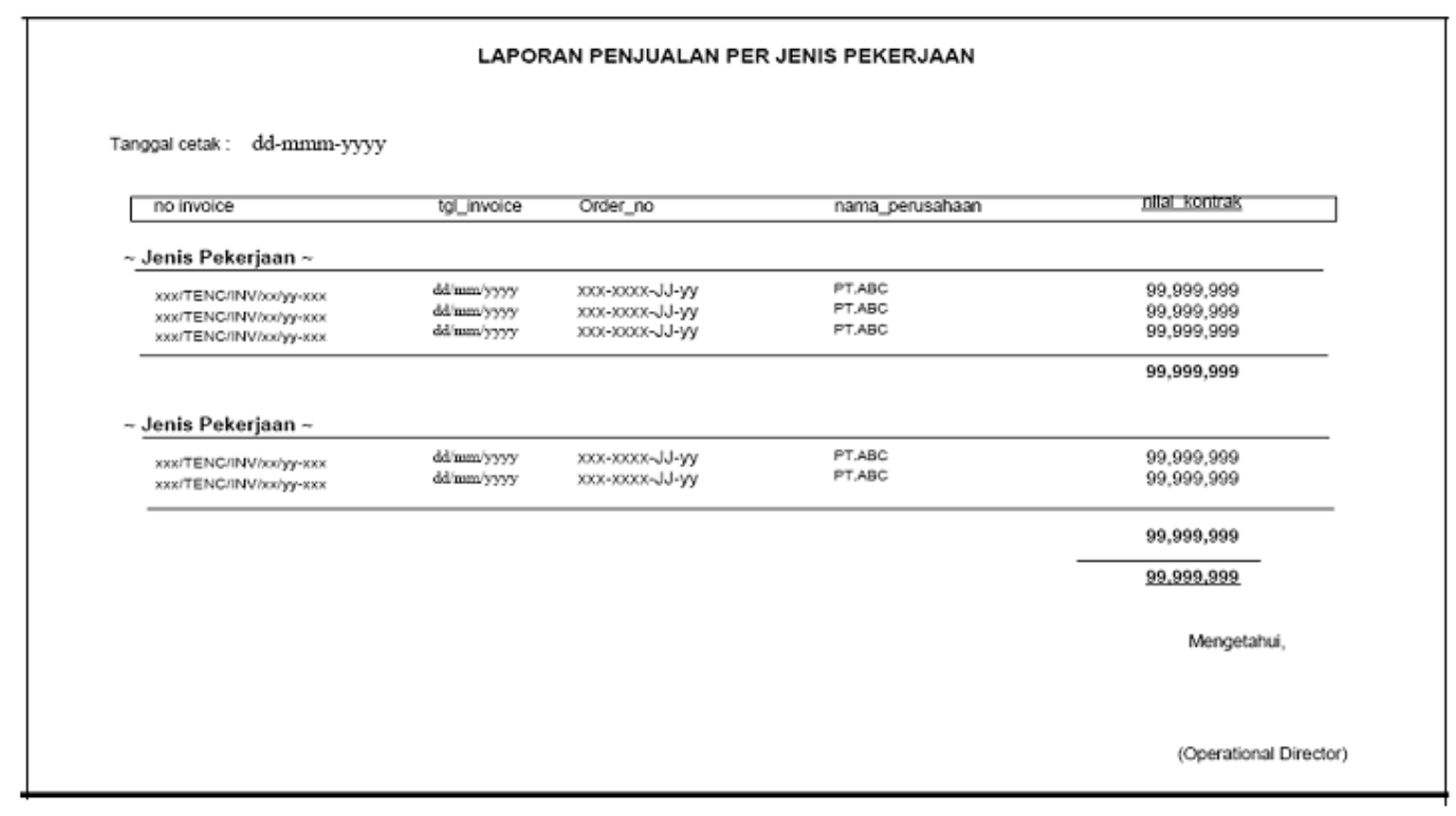

Gambar 11. Laporan penjualan per jenis pekerjaan. 


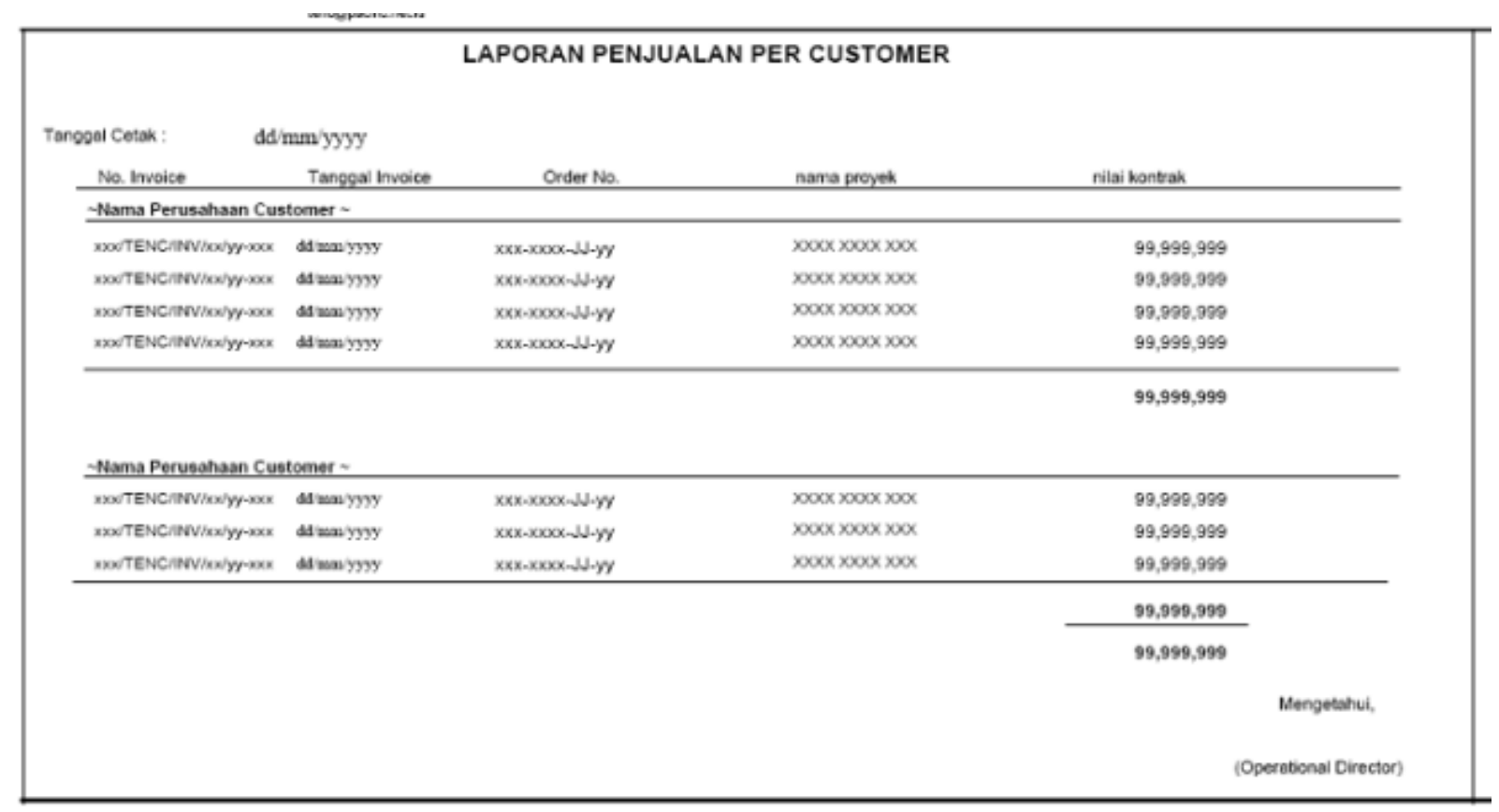

Gambar 12. Laporan penjualan per customer.

\begin{tabular}{|c|c|c|c|c|}
\hline \multicolumn{5}{|c|}{ LAPORAN PIUTANG } \\
\hline No. Imvoice & tgl. invoice & total invoice & no piutang & Total Piutang \\
\hline \multicolumn{5}{|c|}{-Nama Perusahaan Customer - } \\
\hline 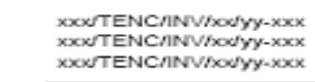 & $\begin{array}{l}\text { dd } \operatorname{man} \text { ysyy } \\
\text { dd } \operatorname{man} \text { ysyy } \\
d d \operatorname{man} \text { ysyy }\end{array}$ & $\begin{array}{l}99.999 .999 \\
99.999 .999 \\
99.999 .999\end{array}$ & $\begin{array}{l}\text { AR- } x \times x \times x \\
\text { AR }-x \times x \times x \\
\text { AR }-x \times x \times\end{array}$ & $\begin{array}{l}99,999,999 \\
99,999,999 \\
99,999,999\end{array}$ \\
\hline \multicolumn{5}{|c|}{-Nama Perusahaan Customer - } \\
\hline 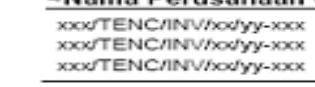 & $\begin{array}{l}\text { dd nam yoyy } \\
\text { dd nambyyy } \\
\text { dd nam-yoyy }\end{array}$ & $\begin{array}{l}99,999,999 \\
99,999,999 \\
99,999,999 \\
\end{array}$ & $\begin{array}{l}\text { AR- } x \times x \times x \\
\text { AR }-x \times x \times x \\
\text { AR- } x \times \times x\end{array}$ & $\begin{array}{l}99,999,999 \\
99,999,999 \\
99,999,999 \\
\end{array}$ \\
\hline & & & & $99,999,999$ \\
\hline & & & Grand Total Piutang & $\underline{99.999 .999}$ \\
\hline & & & & Mengetahul, \\
\hline & & & & (Operational Director) \\
\hline
\end{tabular}

Gambar 13. Laporan piutang. 


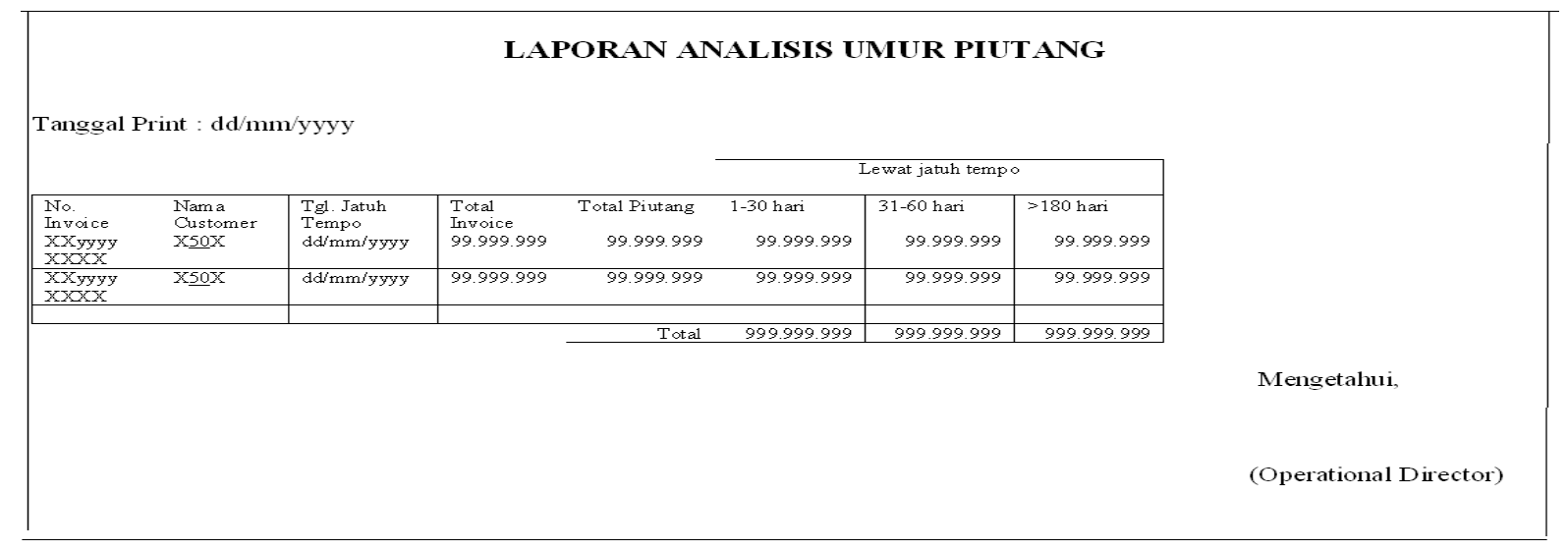

Gambar 14. Laporan analisis umur piutang. 